\title{
Demographic Development Planning in Cities
}

\author{
Jaroslav Burian, Jarmila Zimmermannová, and Karel Macků
}

\begin{abstract}
Currently, the population ageing is one of the greatest economic, social and environmental challenges facing all EU countries. For this reason, the main goal of this study is analysis of the population ageing and its economic aspects. As the main method we used particular instruments of economic and spatial analysis. As the first step, we evaluated the consumption behavior of seniors. In the next step, a spatial analysis of population ageing in the territory of the Olomouc region was processed, models of demographic projection were used to estimate the number of seniors in future years. This information was connected with social services facilities for seniors - the current capacities, the number of candidates and the ratio of refusals are evaluated. Based on this results, an estimation of possible changes needed in the area of social services in the region was presented. At the same time, the riskiest areas of the region were defined regarding the ratio of the seniors to the social services offered. Finally, the Urban Planner model was used to analyse areas for
\end{abstract}

J. Burian $(\bowtie) \cdot$ K. Macků

Department of Geoinformatics, Palacký University

Olomouc, Olomouc, Czech Republic

e-mail: jaroslav.burian@upol.cz; karel.macku@upol.cz

J. Zimmermannová

Department of Economics, Moravian Business College

Olomouc, Olomouc, Czech Republic

e-mail: jarmila.zimmermannova@mvso.cz identifying suitable locations for a new social service facility in accordance with urban planning.

\section{Keywords}

Seniors · Ageing · Economic impact · Spatial · Spatial planning

\subsection{Introduction}

Population ageing is one of the most significant social and economic challenges facing the EU (Burian et al. 2017). At the same time it is a topic that allows to combine economic and spatial aspects of population ageing into one case study.

Regarding actual development of the demographic structure of the population in EU countries, Eurostat published statistics EUROPOP2015 (Eurostat 2017). The median age of the EU-28's population was 42,6 years on 1 January 2016 and it increased by 4.3 years (on average, by 0.3 years per annum) between 2001 and 2016, rising from 38.3 years to 42.6 years. Between 2006 and 2016 the median age increased in all of the EU Member States. Projections foresee a growing number and share of elderly persons (aged 65 and over), with a particularly rapid increase in the number of very old persons (aged 85 and over). These demographic developments are likely to have a considerable impact on a wide range of policy areas with 
respect to economic and financial issues (Eurostat 2017).

In the Czech Republic, the Ministry of Finance is regularly publishing the Macroeconomic forecast of the Czech Republic, including also the issue of population ageing. According to the Ministry of Finance (2017), it is obvious, that the group of older people over the age of 65 continues to grow and on the contrary, the working-age population declines.

We can look at the problem of population ageing with relative and absolute numbers. On one side, the population began to age relatively - there began to be more elderly people and fewer working-age population and children. On the other side, in connection with the good living conditions of the inhabitants, mortality began to decline, and the average lifespan began to lengthen. The population began to age also absolutely - the number of old people (Arltova and Langhamrova 2010).

Based on the economic view, a very important issue is the development of demand of the group of older people - their consumption patterns. This topic is analysed mainly by marketing scientists, which are focusing on specific markets, for example, the market with tobacco products, medical products etc. Higgs et al. (2009) chart consumption by retired households in Great Britain in two areas; ownership of key consumer goods and key components of household spending. The results demonstrate mainly the growing extent of ownership of key goods in retired households and show the differences in proportional expenditure between retired households and the employed (Higgs et al. 2009). Wolf et al. (2014) describe that people often respond to retirement in conjunction with lifestyle changes; many such changes lead to changes in consumption patterns. Changes in consumption expenditures expose consumers to different offers, leading to changes in consumer preferences (Wolf et al. 2014).

Within the regions and cities, the economic issues are strongly connected with urban policy and urban planning. Population ageing and demographic development tend to increase the demand for health care, social security and the care for the disabled and the elderly. Carbonaro (Carbonaro et al. 2016) examined the links between population ageing and demographic development, local economic development prospects, and the financial implications for urban policy. Demographic change impacts on a variety of components of the urban economy. Some of the key areas are urban labour markets, infrastructure planning and housing. But not only urban areas, but also rural places can be affected by these changes. The border between urban and rural can be difficult to differentiate, especially in connection with suburbanization (Paszto et al. 2015, 2016).

There is a limited number scientific studies focusing in more details on population ageing and its consequences with economic and urban planning issues. Therefore, this research is focused on the economic analysis of consumption behaviour of households of retired, the development of retired in the society (age index), possibilities of retirement homes, sustainable urban planning and economic aspects of this issue (Macků et al. 2018; Burian et al. 2018b).

The main goal of this case study is an evaluation of the demographic development, the consumption behaviour of households of retired and inclusion of expected changes to the urban planning in cities. Within this task, the Urban Planner Model (Burian et al. 2015, 2018a) for selecting suitable locations for households of retired was used. The Olomouc region was selected as a case study since detailed economic and geographic data are available for this region. Besides the main goal, the following objectives are formulated:

- evaluation of current situation and trends in the population ageing in the region;

- identification of the riskiest locations from the population ageing perspective;

- Identification the best places for the future cities development.

\subsection{Material and Methods}

\subsubsection{Data}

For the purposes of the analysis of consumption behaviour of pensioners, following data sets were used: Expenditure and Consumption of 
Households statistics - Household Budget Survey, precisely Consumption expenditures annual averages per capita in CZK and detailed development of consumption expenditures of households of pensioners without EA members (Czech Statistical Office 2017). For the prediction of the development of retired in the society, the following data sources were used: Social services establishments, Selected social security data, Five years population structure and Life tables. All these datasets were also provided by the Czech Statistical Office (Czech Statistical Office 2017). A total of more than 120 vector layers covering Urban Planner Model factors (see the section about Urban Planner) were used as the input for land suitability calculations. These layers are collected according to the regulations of Act No. 183/2006 Coll., the Construction Act, by all regional planning offices in the Czech Republic as part of the analytical material for planning (Burian et al. 2016). The source of the data is more than 40 organisations or private companies (e.g. Czech Geological Survey; Czech Hydrometeorological Institute; Czech Statistical Office; Czech Office for Surveying, Mapping, and Cadastre etc.). The spatial accuracy of the data corresponds to the Cadastral Map - scale 1:2000.

\subsubsection{Methods}

\subsubsection{Analysis of Consumption Behaviour of Pensioners}

Analysis of consumption behaviour of pensioners serves for the estimation of potential areas for additional investments into new social services. For the purposes of this analysis, we use Expenditure and Consumption of Households statistics - Household Budget Survey, precisely Consumption expenditures - annual averages per capita in CZK and detailed development of consumption expenditures of households of pensioners without economic active (EA) members. We provide a comparative analysis of households of employees in total and households of pensioners without economic active) members; the difference in consumption patterns is calculated as both difference in CZK and difference in $\%$.

\subsubsection{Prediction of the Development of Retired in the Society}

Regarding the ageing of the population and the analysis of the consumption behaviour of seniors, the demographic situation in the territory of the Olomouc Region was evaluated in this study (Macků et al. 2018). In the statistical surveys, 65 years is usually used as the age of retirement. This statement also follows the definitions used at international level by organisations such as the UN or Eurostat. Of course, the age limit of 65 years does not always coincide with the actual start of retirement. The demographic projection is used to predict the future development of the population. The most commonly used population prognosis method is a component method, that takes the age structure of the population in 5-year categories as a starting point and shifts population numbers by age group to higher age levels using survival probabilities (O'Neill et al. 2001). These numbers are reduced by the number of deaths and enlarged by the number of births. The unborn population is calculated on the basis of expected development of fertility rates by the age of women. Migration is not considered in this component method.

As a tool for identification of elderly areas, spatial distribution of ageing index is used. The ageing index is calculated as the ratio between the number of people at the age over 65 years per 100 children in age $0-14$. It is often used as an indicator of demographic ageing of the population. Values displayed in the map can quickly deliver the information about current state and also development over past decade. In the same way, the spatial distribution of retirement homes with their capacity is evaluated and helps to determine zones within sufficient social services.

\subsubsection{Urban Planner Suitability Analysis}

To identify the suitable (optimal) locations for households of retired within the municipalities, land suitability analysis in the Urban Planner 
Model was performed (Burian et al. 2017). The Urban Planner is an analytic extension for Esri ArcGIS for Desktop designed to evaluate the land suitability and to detect the most suitable areas for spatial development. The model was developed at the Department of Geoinformatics, Palacký University in Olomouc (Burian et al. 2015, 2018a). The model uses a multi-criteria analysis, respects the principles of sustainable development, and allows for the creation of several land use and land suitability scenarios. The core of the Urban Planner Model focuses on the evaluation of land suitability according to input data, it's values and weights. Land suitability is analyzed in three levels (pillars, factors, and layers) for the five predefined categories of land use. For the analysis described in this case study, only one category of land-use (specific type housing) was calculated.

The total land suitability is calculated according to the setting of the weights between the three classes (the three pillars): environmental, social, economic. Weights can acquire values from 0 to 100; the sum of the weights of all three pillars must be equal to 100. Each of the three pillars (classes) consists of factors. Factors are divided into three groups - positive, negative and limits, and are assigned to the pillars. As in the case of pillars, the combination of factors is based on weighted overlay method. The following factors were used for land suitability analysis:

- ENVIRONMENTAL PILLAR - Water bodies protection, Nature protection, Mineral resources protection, Soil and forest protection

- SOCIAL PILLAR - Slope aspect, Kindergarten accessibility, Elementary school accessibility, Grocery store accessibility, Public spaces accessibility, Bus stops and public transport accessibility, Trains stops accessibility, Density of forests, Distance of rivers, Density of build-up areas, Air pollution, Noise pollution, Population density, Radon risk, Cultural and social protection

- ECONOMIC PILLAR - Population density, Radon risk, Slope, Electric power supply, Drinking water supply, Gas supply, Wastewater management, Heat supply, Fiber-optic internet connection, Distance from roads,
Distance from railroads, Flood hazard, Geological hazard, Specific infrastructure protection (Fig. 14.1)

The weights for input factors and pillars were calculated with the commonly used Saaty's method (Saaty 1983), which makes it possible to define the weights for several criteria as objectively as possible. All selected factors follow the standard layer used in a master plan creation and reflect consumption behaviour of households of retired (e.g. factor grocery store accessibility, public transport accessibility etc.). The weights were tested and calibrated in several regions in the Czech Republic (Olomouc Region, Ostrava Region, Vysocina Region, and Prague Region).

\subsection{Results and Discussion}

By 31st December 2016, 122,257 people over 65 years lived in the Olomouc Region and there were 148,420 registered recipients of pensions. It is clear that the age of 65 years as the retirement age is currently overestimated, also because many people decide for early retirement (Czech Statistical Office 2015). In connection with increasing of the retirement age, gradual wiping of this difference can be expected. Ageing is proved by a simple trend (Fig. 14.2). The number of persons older than 65 years is increasing approximately by 3500 persons per year. On the other side, amount of pension recipients does not have so clear trend, and in some years, slight decrease can be observed.

The population prediction in the Olomouc region was calculated for each age group at 5-year steps up to the year 2035 (see Table 14.1). The prediction results in both the total decrease in the number of inhabitants in the region and the gradual increase of the age group over 65 years. These two trends clearly indicate the ageing of the population, as also evidenced by ageing index values. Average value of the ageing index in the year 2016 is 128 , which is slightly higher than the national average (120). Figure 14.3a) shows its development in last 


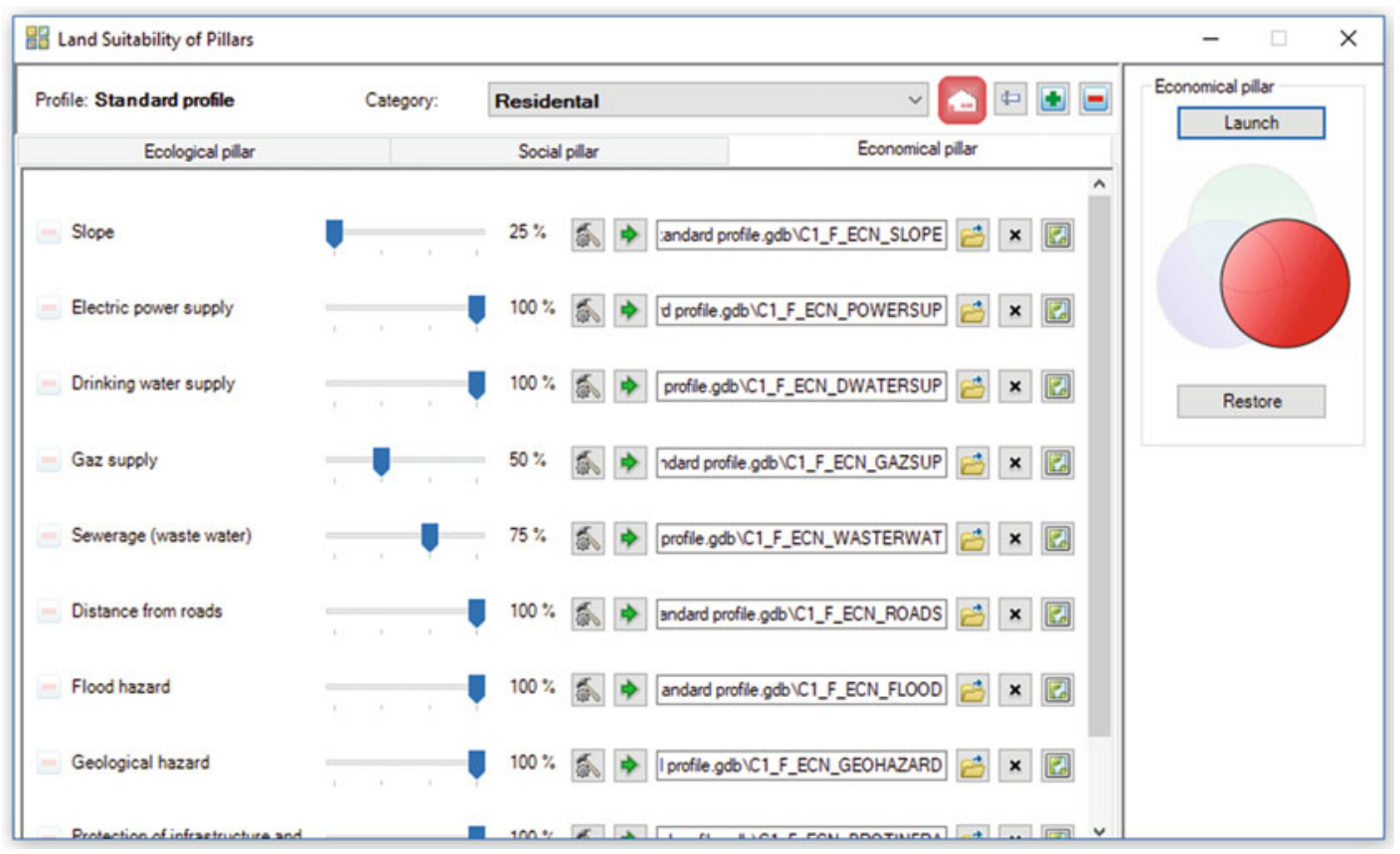

Fig. 14.1 Example of economic factors' weights (Source: Authors)

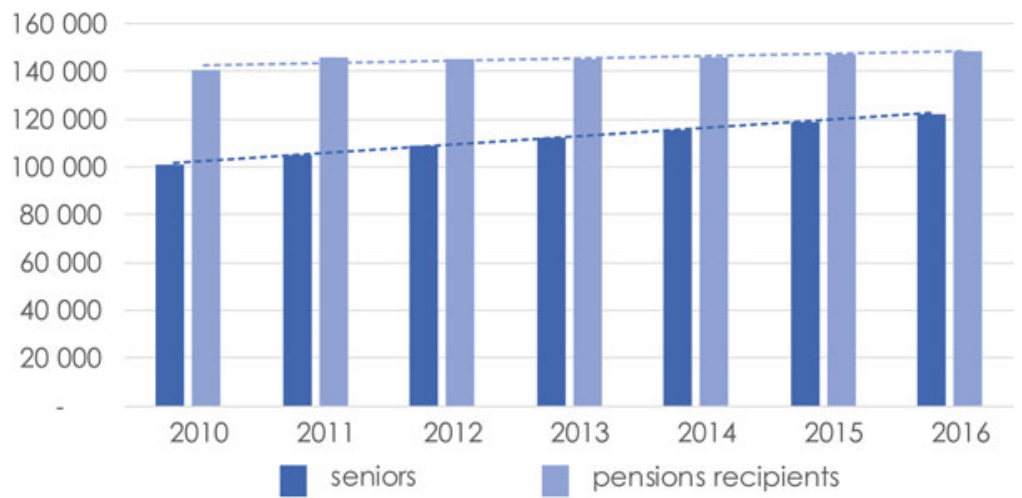

Fig. 14.2 Development of seniors in Olomouc region. (Source: Authors, CZSO 2017)

Table 14.1 Demographic projection

\begin{tabular}{l|l|l|l|l|r}
\hline Age group & 2015 & 2020 & 2025 & 2030 & 2035 \\
\hline $0-14$ & 95,884 & 94,781 & 84,867 & 75,753 & 69,509 \\
\hline $15-64$ & 420,019 & 399,827 & 390,581 & 378,801 & 363,866 \\
\hline $65+$ & 118,815 & 132,695 & 137,858 & 139,254 & 137,791 \\
\hline
\end{tabular}

Source: CZSO (2015, Authors)

10 years: only 104 municipalities tend to be younger, the remaining 294 suffer from increase. Average values in these two dichotomous categories are unequal, too - the average decrease is $16 \%$, average increase $38 \%$. Therefore, ageing not only predominates, but it is also more intensive.

With the increasing number of seniors, this research asks if it is possible to provide this 


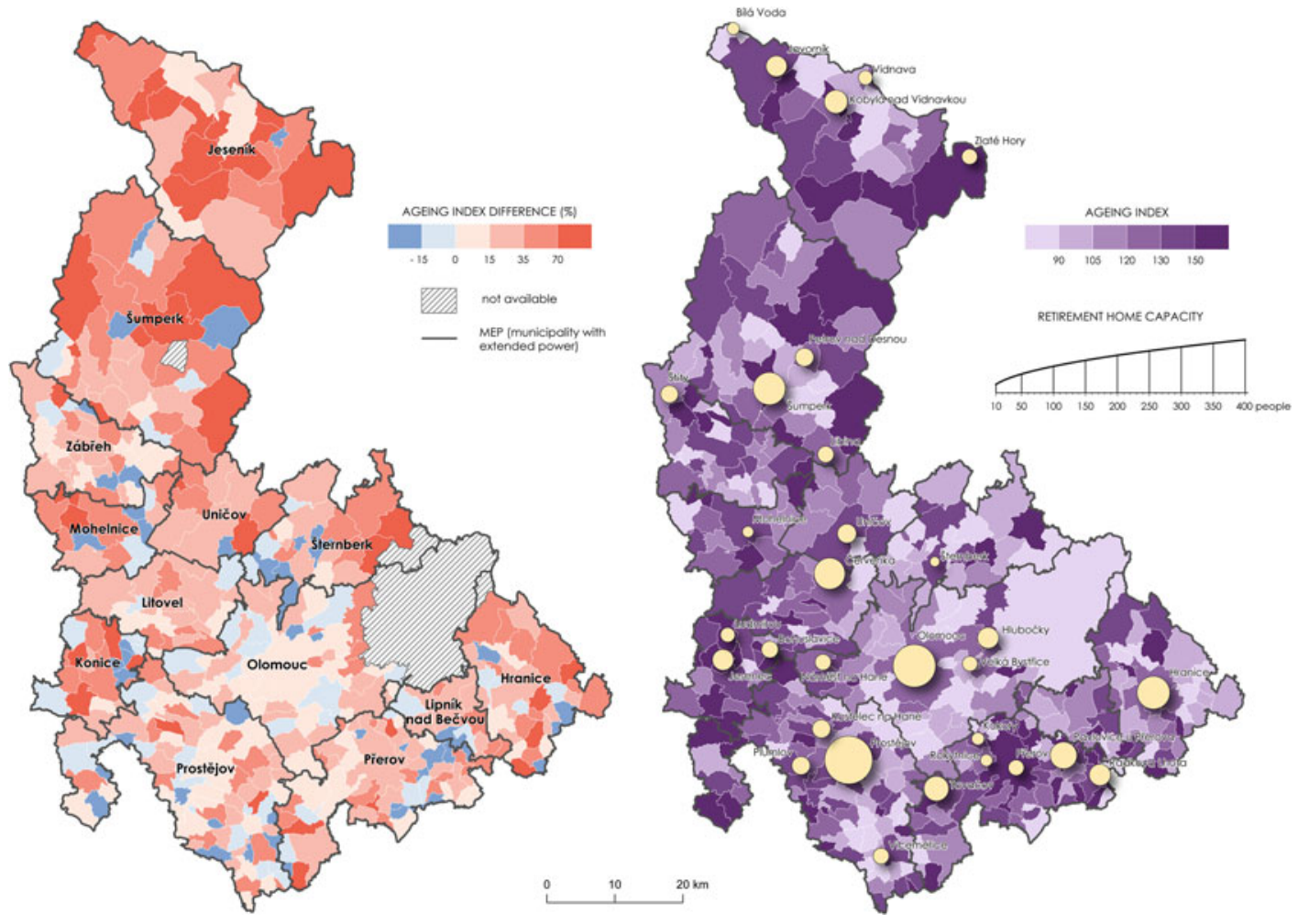

Fig. 14.3 Ageing index and its development. (Source: Authors, CZSO 2017)

population group with sufficient social services, necessary care and enable them to live a dignified and quality life. The comparison of selected consumption expenditures in two groups of households - households of employees in total and households of pensioners without active economic members are described in Table 14.2 and Fig. 14.4. Focusing on consumption expenditures of households of pensioners without economic active members, it is obvious, that there are 3 groups of significantly higher consumption expenditures in comparison with households of employees (food and non-alcoholic beverages; housing, water, electricity, gas and other fuels; health) and also groups of significantly lower consumption expenditures (clothing and footwear; transport; education; restaurants and hotels). This conclusions are used in the Urban Planner Model to set higher weights for these factors to calculate land suitability for housing for seniors.
There are currently several types of facilities providing social services in the Olomouc Region. For this research, retirement houses have been taken into account. In 2016 there were 34 such facilities with a total capacity of 2674 people. The current spatial distribution of social facilities equally covers the territory of the Olomouc Region. Less accessibility is only in the northern part of the region between MEP (the municipality with extended power) Jeseník and Šumperk, as well as MEP Mohelnice and Zábřeh do not have high capacity (see Fig. 14.3b). The facilities of social services are (as expected) located in municipalities with a higher number of inhabitants or a higher proportion of people aged $65+$, but the dependence between the number of inhabitants and the total capacity of the facility is not significant.

Evaluation of demographic data indicates long-term ageing in many of Olomouc region municipalities. The highest increase in the ageing 
Table 14.2 Comparison of selected consumption expenditures in 2016 in the Czech Republic

\begin{tabular}{l|r|l|l|l}
\hline & \multicolumn{3}{l}{ Households } & \multicolumn{2}{l}{ Differences in consumption patterns } \\
\cline { 2 - 5 } Consumption expenditure & $\begin{array}{l}\text { Employees } \\
\text { in total }\end{array}$ & $\begin{array}{l}\text { Pensioners without } \\
\text { EA members }\end{array}$ & $\begin{array}{l}\text { Difference in } \\
\text { CZK }\end{array}$ & $\begin{array}{l}\text { Difference in } \\
\%\end{array}$ \\
\hline Food and non-alcoholic beverages & 23,854 & 29,244 & 5390 & 122.60 \\
\hline Alcoholic beverages, tobacco & 3572 & 3757 & 185 & 105.18 \\
\hline Clothing and footwear & 7444 & 3836 & -3608 & 51.53 \\
\hline $\begin{array}{l}\text { Housing, water, electricity, gas and other } \\
\text { fuels }\end{array}$ & 24,175 & 34,063 & 9888 & 140.90 \\
\hline Furnishings, household equipment etc. & 8059 & 7526 & -533 & 93.39 \\
\hline Health & 2912 & 4565 & 1653 & 156.77 \\
\hline Transport & 16,108 & 8459 & -7649 & 52.51 \\
\hline Communication & 5310 & 4562 & -748 & 85.91 \\
\hline Recreation and culture & 12,768 & 10,553 & -882 & 82.65 \\
\hline Education & 916 & 34 & -4364 & 3.71 \\
\hline Restaurants and hotels & 8573 & 4209 & -5277 & 49.10 \\
\hline Miscellaneous goods and services & 16,468 & 11,191 & & 67.96 \\
\hline
\end{tabular}

Source: CZSO (2017, Authors)

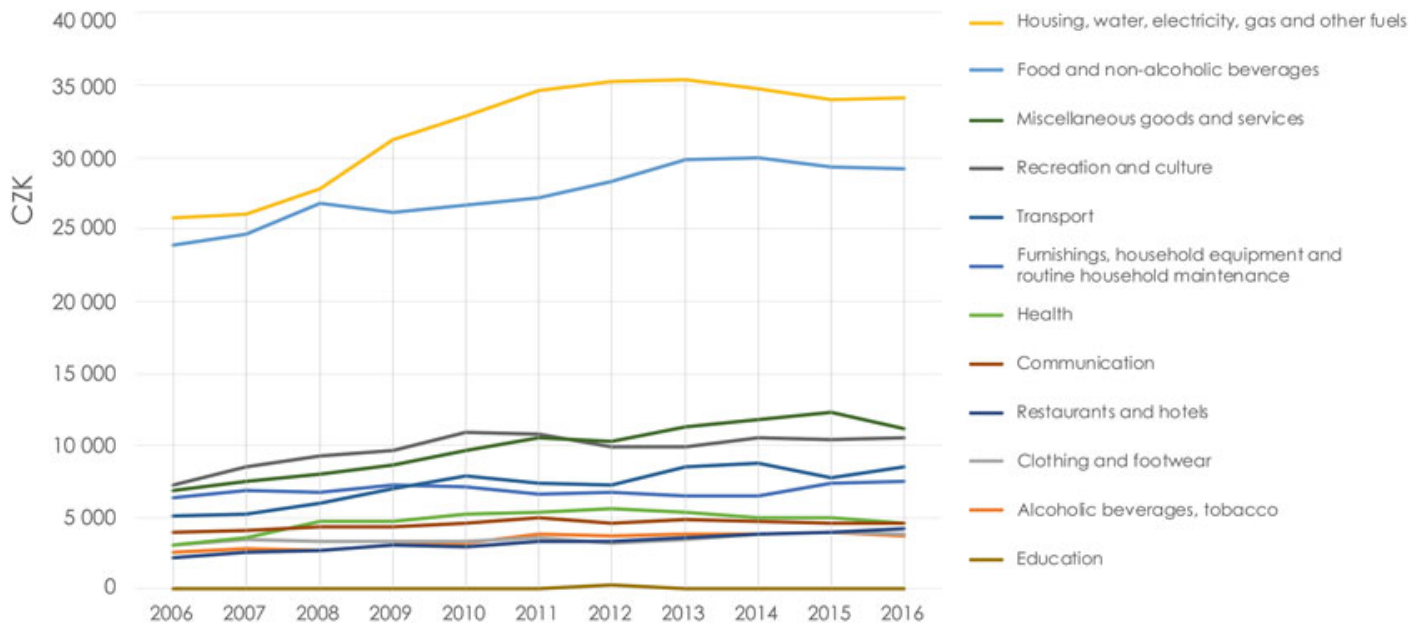

Fig. 14.4 Consumption expenditures of households of retired, annual averages per capita in CZK. (Source: Authors, CZSO 2017)

index is in the northern part of the region and at east-north borders (municipalities Norberčany, Rejchartice and Mírov). On the other hand, biggest decrease is typical for small municipalities (less than 500 citizens - e.g. Šlégov, Hačky and Provodovice). These villages are located close to bigger cities, so the changes can be attributed to suburbanization processes.

Regarding this demographic development, new investments in social facilities should be expected. Considering the simple dependence between the current number of seniors and the capacities of retirement houses, a very simplified estimate can be made to illustrate how many new facilities with sufficient capacity will need to be built in the future.

Expecting approximately the same proportion of seniors using these services, it will be necessary to increase the capacity of the facility by approximately 415 places, keeping the average capacity of 70 people per facility, six new social service facilities will be needed. Unfortunately, 
retirement homes are not able to meet the needs of all applicants, much remains to be refused. The Ministry of Labor and Social Affairs records the rejected applications mostly in the category of retirement homes $(65,764$ in the Czech Republic, 2016). There are no indicators comparing rejected applications to all applications, rejected applications can be relativized e.g. to 1000 seniors. In this case, the worst situation is in Jihomoravský region (56 rejected per 1000 seniors), Olomouc region registered 29 rejected applications per 1000 seniors, which is slightly worse than the national average (25 per 1000).

Focusing on economic aspects of population ageing and consequent planning of facilities for seniors, Fig. 14.5 shows us increasing expenditures (in thousand CZK) on homes for seniors, homes with a special regime and homes for people with disabilities.

Fig. 14.5 Social services expenditures in thousands CZK. (Source: Authors, CZSO 2017)

Fig. 14.6 Retirement homes - capacity. (Source: Authors, CZSO 2017)
Since the highest yield of expenditures is represented by homes for seniors, it is interesting to focus on more details on the structure of ownership of these homes. As you can see in Fig. 14.6, the number of state, regional and municipal houses for seniors is decreasing, on the other hand the number of non-state houses for seniors is increasing.

Based on the development of ownership of houses for seniors, the question of financing of planning and building of new social services facilities represents key issue for responsible local authorities. Dealing with increasing number of seniors and simultaneously higher demand for new facilities and houses for seniors, we can expect significant financial burden on both public and private budgets. On the other hand, based on the survey, almost $80 \%$ of seniors would prefer to finish one's days at home. This statement opens new discussion about enhance of investments into
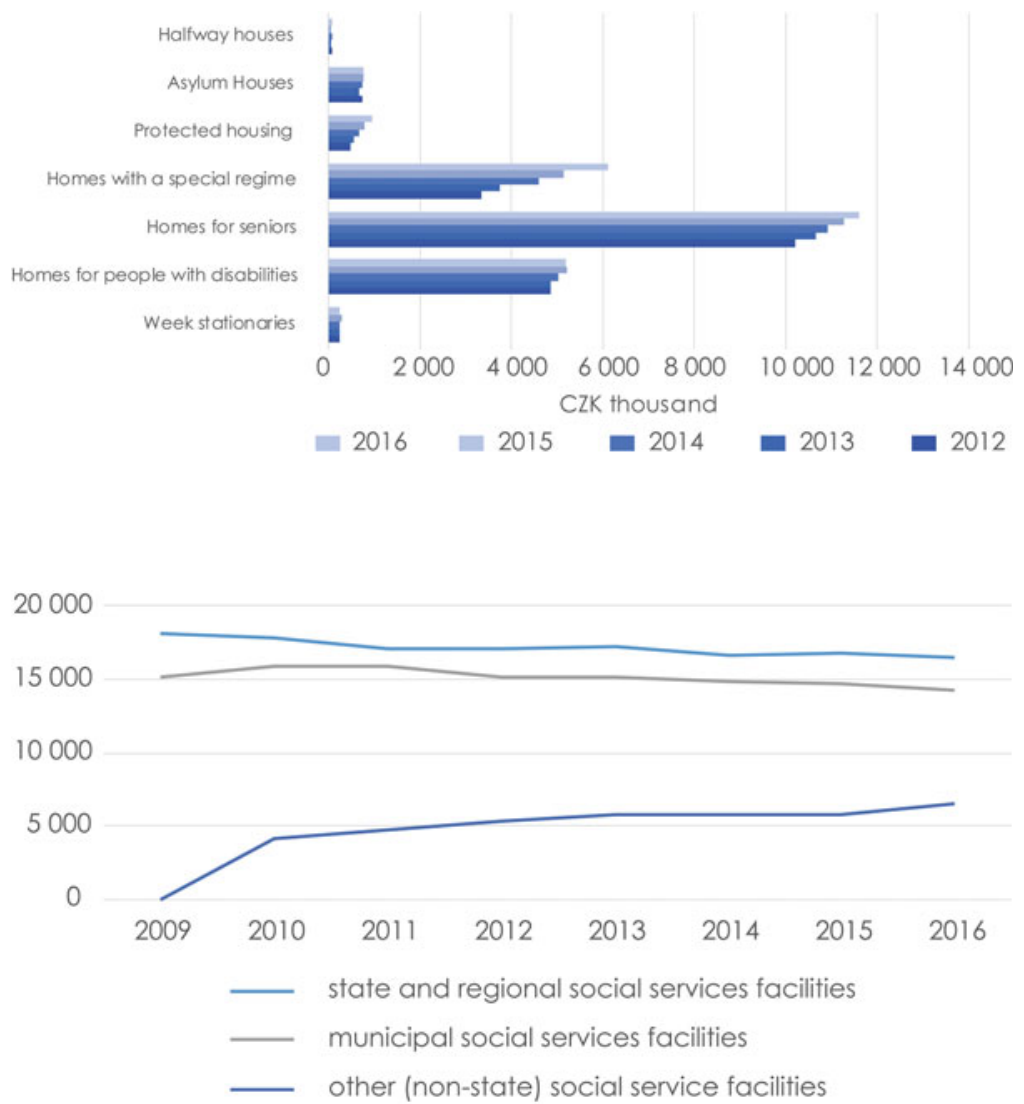
terrain social services, that would provide only the necessary help to the old people.

Comparing our results with other scientific studies, there is a lack of studies focusing simultaneously on economic aspects of population ageing and urban planning. We can find mainly studies focusing on development and testing of different models of healthcare planning based on more variables, including demographic variables, technological innovations, epidemiological changes and socioeconomic factors (Chernichovsky and Markowitz 2004; Birch et al. 2013; Mason et al. 2015; Basu and Pak 2016; Birch et al. 2017). Based on these scientific studies and results of our research, it is obvious, that we should plan social and healthcare services facilities not only with respect to demographic development; therefore the model should be more complex, including different variables which can be part of particular decision-making.

As the last step within this case study, Urban Planner Model was used to calculate land suitability for housing. Information about consumption expenditures was used to define input factor and set their weights. The final results of the land suitability calculations are raster layers, that can be visualised in the map. Because of the raster resolution $(10 \mathrm{~m} / \mathrm{pixel})$ and the study area (whole Olomouc Region), the simple web map application in Esri ArcGIS Online was created
(Fig. 14.7). The application allows to zoom in to see detailed situation within the area of each municipality in the region (Fig. 14.8). For better orientation, in larger scale, boundaries of existing and proposed build up are being used. The values of land suitability range from 0 (the lowest suitability) to 100 (the highest suitability). Areas with no values represent places disqualified for suitability due to limits (e.g., flooding areas or protection zones). The map can be used for the detection of the most suitable places for new households. Similar results from Urban Planner Model (raster layers of land suitability) has been used in several regions in the Czech Republic (e.g. Olomouc Region, Ostrava Region, Vysocina Region) as supporting material for planning decisions at urban planning offices.

\subsection{Conclusion}

The main goal of this study was to analyse the population ageing issue with detailed focus on Olomouc region and to discuss its economic and spatial aspects. For the purpose of the main goal achievement, we used economic and spatial analysis. Regarding the evaluation of current situation and trends in the population ageing in the region, we can say that our analyses prove a trend of population ageing in the region. In comparison

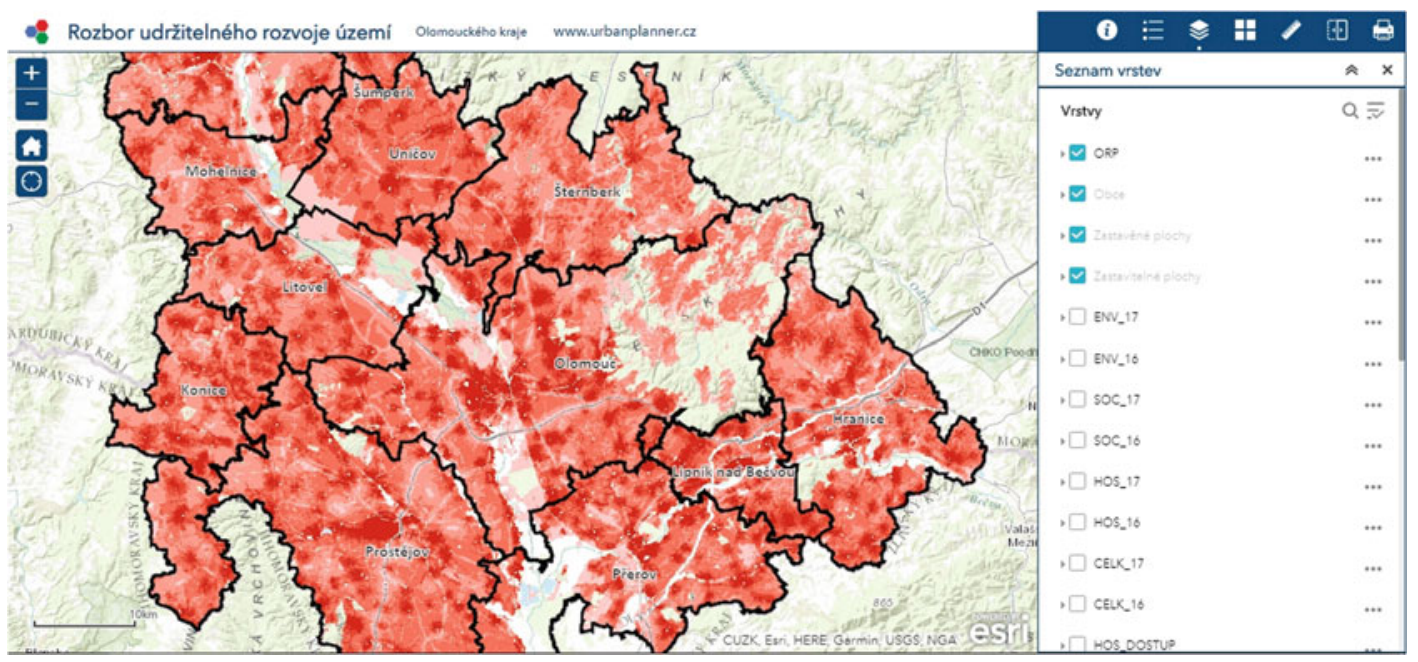

Fig. 14.7 Web Map Application with land suitability for housing. (Source: Authors) 


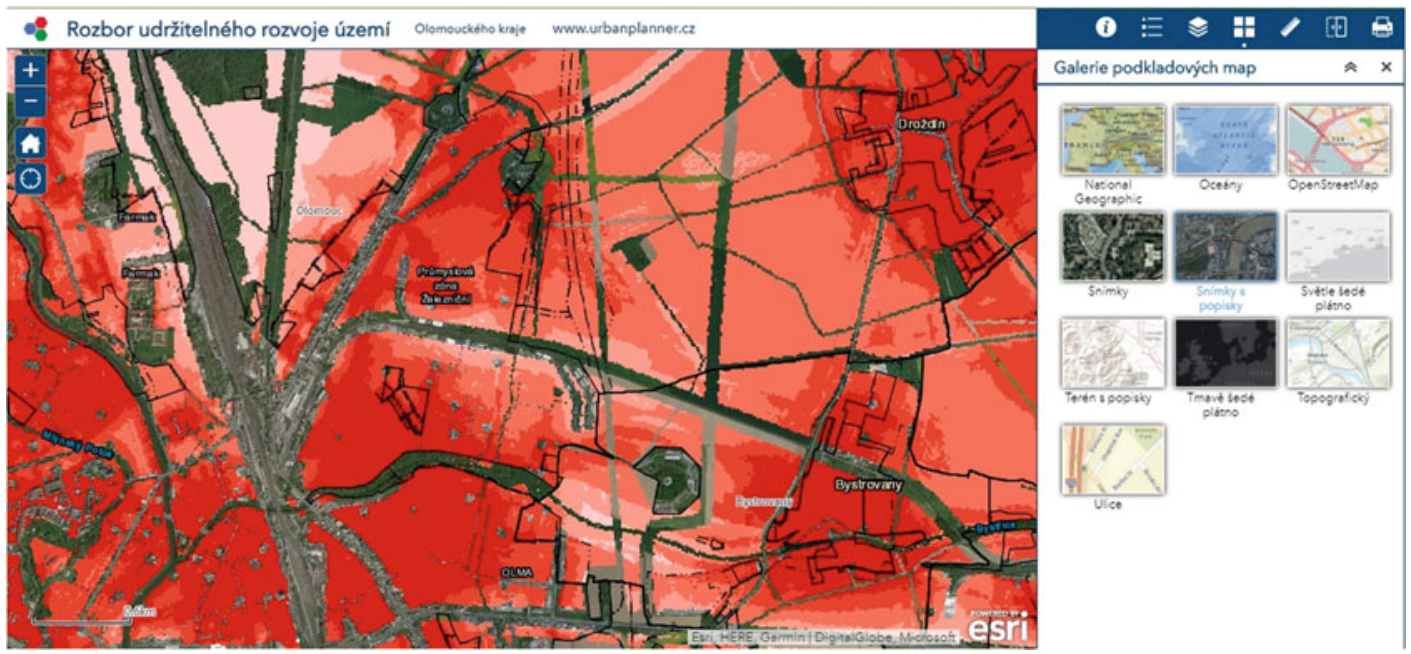

Fig. 14.8 Web Map Application with land suitability for housing. (Source: Authors)

with national numbers, the situation in the Olomouc region is a little worse than the national average (ageing index, retirement homes rejected applications etc.).

Focusing on identification of the riskiest locations from the population ageing perspective, thanks to spatial analysis and visualization, the most problematic areas can be discovered. At the same time, the spatial distribution of retirement homes is assessed - they are appropriately placed across the region. In connection with home capacity and the current trend of rejection of applications, many new facilities will be probably needed.

Regarding economic aspects, we can observe increasing demand for social service facilities, connected with population ageing. Since there are not only state, regional or municipal owners of these facilities, moreover the share of private facilities is increasing, particularly in case of houses for seniors, the future financial burden will be divided between public and private stakeholders.

Finally, the land suitability assessment of the Olomouc region was analysed. All results were obtained by the Urban Planner Model using a multi-criteria analysis as the main computational method. The highest consumption expenditures were used to refine default input factor and their weights to reflect demands of the retired group.
The final output from the model was the raster layer of land suitability, that was visualised in the web map application. The application can be used to detect the most suitable places for the new household in each municipality in the Olomouc region.

The future research can be focused on deeper spatial analysis, e.g. network analysis describing exact coverage of region by particular retirement home. At the same time, sophisticated models for urban planning can be used for detailed searching of suitable locations for new social facilities (e.g. Urban Planner). This kind of approach allows to include another economic data together with spatial information and then perform better complex analysis.

\section{References}

Arltova, M., \& Langhamrova, J. (2010). Migration and ageing of the population of the Czech Republic and the EU countries. Prague Economic Papers, 19(1), 54-73.

Basu, K., \& Pak, M. (2016). Will the needs-based planning of health human resources currently undertaken in several countries Lead to excess supply and inefficiency? Health Economics, 25(1), 101-110.

Birch, S., Mason, T., Sutton, M., \& Whittaker, W. (2013). Not enough doctors or not enough needs? Refocusing health workforce planning from providers and services to populations and needs. Journal of Health Services Research and Policy, 18, 107-113. 
Birch, S., Tomblin, M. G., MacKenzie, A., Whittaker, W., \& Mason, T. (2017). Will the need-based planning of health human resources currently undertaken in several countries Lead to excess supply and inefficiency? A comment on Basu and Pak. Health Economics, 26(6), 818-821.

Burian, J., Stastny, S., Brus, J., Pechanec, V., \& Vozenilek, V. (2015). Urban planner: Model for optimal land use scenario modelling. GEOGRAFIE, 120 (3), 330-353.

Burian, J., Brychtova, A., Vavra, A., \& Hladisova, B. (2016). Analytical material for planning in Olomouc, Czech Republic. Journal of Maps, 12(4), 649-654.

Burian, J., Zimmermannová, J., \& Macků, K. (2017). Urban planner as a tool for demographic development planning in the cities. In Proceedings from the 8th annual international scientific conference "Region in the development of society 2017.” Mendel University in Brno.

Burian, J., Stachova, M., \& Vondrakova, A. (2018a). Land suitability assessment of the Olomouc region: An application of an urban. Planner Model Journal of Maps, 14(1), 73-80. https://doi.org/10.1080/17445647.2018. 1493407.

Burian, J., Macků, K., Zimmermannová, J., \& Kočvarová, B. (2018b). Spatio-temporal changes and dependencies of land prices: A case study of the city of Olomouc. Sustainability, 10(12), 4831. https://doi.org/10.3390/ su10124831.

Carbonaro, G., Leanza, E., McCann, P., \& Medda, F. (2016). Demographic decline, population aging, and modern financial approaches to urban policy. International Regional Science Review, 41(2), 210-232.

Chernichovsky, D., \& Markowitz, S. (2004). Aging and aggregate costs of medical care: Conceptual and policy issues. Health Economics, 13(6), 543-562.

CZSO (Czech Statistical Office). (2015). Seniors in Olomouc region. https://www.czso.cz/

CZSO (Czech Statistical Office). (2017). Household budget survey. https://www.czso.cz/
EUROSTAT. (2017). Population structure and ageing. http://ec.europa.eu/eurostat/statistics-explained/index. php/Population_structure_and_ageing

Higgs, P. F., Hyde, M., Gilleard, C. J., Victor, C. R., Wiggins, R. D., \& Jones, I. R. (2009). From passive to active consumers? Later life consumption in the UK from 1968-2005. The Sociological Review, 57(1), 102-124.

Macků, K., Zimmermannová, J., \& Burian, J. (2018). Economic and spatial analysis of population ageing. In P. Dvořáková \& P. Baisa (Eds.), Proceedings of the 22nd international conference current trends in public sector research. Brno: Masaryk University.

Mason, T., Sutton, M., Whittaker, W., \& Birch, S. (2015). Exploring the limitations of age-based models for health care planning. Social Science \& Medicine, 132, 11-19.

MFCR (Ministry of Finance of the Czech Republic). (2017) Macroeconomic forecast. http://www.mfcr.cz/ en/statistics/macroeconomic-forecast/

O’Neill, B. C., Balk, D., Brickman, M., \& Erza, M. (2001). A guide to global population projections. Demographic Research, 4, 203-288. https://doi.org/10. 4054/DemRes.2001.4.8. ISSN:1435-9871.

Paszto, V., Brychtova, A., Tucek, P., Marek, L., \& Burian, J. (2015). Using a fuzzy inference system to delimit rural and urban municipalities in the Czech republic in 2010. Journal of Maps, 11(2), 231-239. https://doi. org/10.1080/17445647.2014.944942.

Paszto, V., Burian, J., Marek, L., Vozenilek, V., \& Tucek, P. (2016). Membership of Czech municipalities to rural and urban areas: A fuzzy-based approach. GeografieSbornik CGS, 121, 1.

Saaty, T. (1983). Priority setting in complex problems. IEEE Transactions on Enigneering Management, 3, 140-155.

Wolf, F., Sandner, P., \& Welpe, I. M. (2014). Why do responses to age-based marketing stimuli differ? The influence of retirees' group identification and changing consumption patterns. Psychology \& Marketing, 31 (10), 914-931.

Open Access This chapter is licensed under the terms of the Creative Commons Attribution 4.0 International License (http://creativecommons.org/licenses/by/4.0/), which permits use, sharing, adaptation, distribution and reproduction in any medium or format, as long as you give appropriate credit to the original author(s) and the source, provide a link to the Creative Commons licence and indicate if changes were made.

The images or other third party material in this chapter are included in the chapter's Creative Commons licence, unless indicated otherwise in a credit line to the material. If material is not included in the chapter's Creative Commons licence and your intended use is not permitted by statutory regulation or exceeds the permitted use, you will need to obtain permission directly from the copyright holder. 